\title{
Geographic Information System of Government Service Office Mapping in Merauke Regency
}

\author{
Susanto $^{1}$, Lilik Sumaryanti ${ }^{2}$, Suwarjono ${ }^{3}$, Teddy Istanto ${ }^{4}$ \\ Informatics Engineering Department \\ Universitas Musamus \\ Merauke, Indonesia \\ 1'susanto@unmus.ac.id, ${ }^{2}$ lilik@unmus.ac.id, ${ }^{3}$ suwarjono@unmus.ac.id, ${ }^{4}$ teddyistanto@gmail.com
}

\begin{abstract}
Government agency is one of the elements supporting the implementation of regional autonomy in any fields applying decentralization tasks. Service offices in Merauke Regency consist of 20 regional agencies, 7 regional technical institutions, 1 regional public hospital, 1 civil service police unit, and 11 regional technical implementation units. Each office has different service, so a geographic information system of the government service office in Merauke is created to help people searching for information about location, office profile, service, and procedure of the service office. The system designed is a webbased geographic information system using programming language PHP and Google Map API as a media to display the map of Merauke Regency. The system is tested using Black Box method and questionnaires. The result of the test shows that geographic information system of government service office mapping in Merauke Regency can display location, office information, as well as service at the government service office.
\end{abstract}

Keywords: Geographic Information System; Government Agency; Mapping; Merauke Regency

\section{INTRODUCTION}

Merauke is one of regencies in Papua Province that has been expanded and developed in several fields, especially in public service. Based on the data of Regional Government, the area of Merauke, in 2015 before being expanded, is 119.749 $\mathrm{km}^{2}$ (29\% of the total area of Papua). After being expanded, total area of Merauke is $49.791,63 \mathrm{~km}^{2}$ consisting of 20 districts, 8 sub-districts, and 160 villages. Merauke is one of 29 regencies/cities in Papua located in the south with the largest area. Administratively, Merauke Regency has 20 districts, where Waan District is the widest district, reaching $5,416.84 \mathrm{~km}^{2}$ while Semangga District is the smallest district with an area of only $326.95 \mathrm{~km}^{2}$ or only 0.70 percent of the total area of Merauke Regency. While the area of water in Merauke Regency reaches 5,089.71 $\mathrm{km}^{2}$ [1]

Government agency is one of the elements supporting the implementation of regional autonomy in any fields applying decentralization tasks. Government functions to provide public service needed by people, starting from the services of making regulation to other services to the people's need in the fields of education, health, and others. Agency and institutions included in public service and government department are spread throughout the entire city of Merauke. So far, there is no official website or socialization on information about government service locations for the public. The information from the site of Regional Government of Merauke Regency in 2016 only provides data of the names of registered government agency without attaching the address and types of service offered to the public. The services offered by each government agency are certainly different. Procedure of each agency in giving service is different as well. People should ask the local people about the information of the government office location and types of service provided by each government agency.

Geographical Information System (GIS) is a computerbased information system for storing, managing and analyzing, as well as calling geographically referenced data that has developed rapidly in the last five years. The benefits of GIS are to provide convenience to users or decision makers to determine the policies to be taken, especially those relating to spatial aspects. [2]

Geographic Information System (GIS) is defined as information system used to input, to save, to recall, to process, to analyze, and to obtain geographic reference data or geospatial data for supporting decision making in planning and managing the utilization of the land, natural resources, transportation, city facility, and other public services. GIS can be one of the solutions for the unavailability of official site or the lack of information about the location of government agency in the community which make them difficult to find the information about the office address. The solution of the problem is by making a geographic information system on the mapping of the government agency office in Merauke Regency.

This technology is designed to help collect data, store data and analyze objects along with important and critical geographic data to be analyzed. The Geographic Information System application has been applied in various fields. With the development of technology, especially in the field of internet this Geographic Information System has been developed into a web-based geographic information system. [3]. 


\section{METHOD}

\section{A. Database Table Structure}

The relation between tables can be seen in Figure 1. Some relations among the stated tables are as follow:

1) Office table and Type table: This relation is made because the office table needs type code that will be used to differentiate the types of government service office.

2) Detail table and Service table: This relation is made because the detail table needs service code that will be combined with the office table.

3) Detail table and Office table: This relation is made because the detail table needs office code that will be combined with the service table to be a complete data.

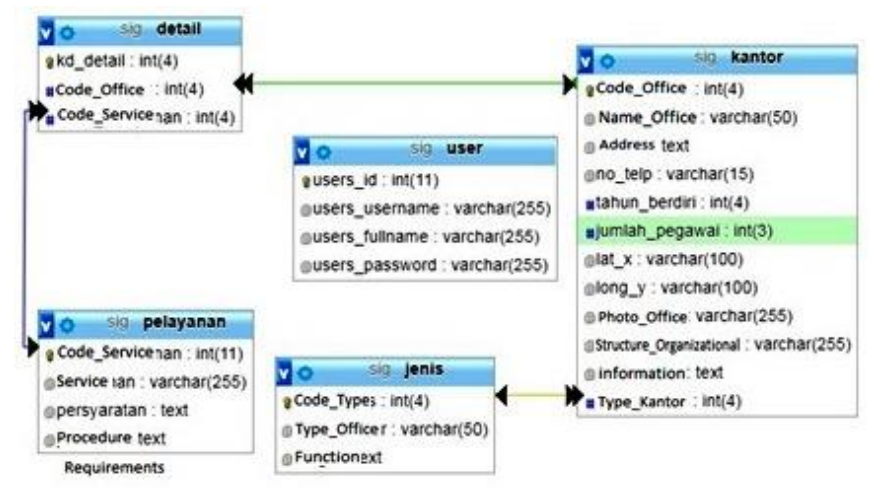

Fig. 1. Relations database

\section{B. Context Diagram}

Context Diagram (CD) is a diagram consisting of a process and describes the scope of a system. Admin login and enter information data about user data, office data, type data, service data, and office detail data into the system which will then be processed and provide output in the form of user information, office information, type information, service information, office detail information and reports from each process. Users enter the name of the office or service into the system then the system will provide output in the form of information sought by the name of the office, services and reports from the government service office sought. Context diagram is a data flow diagram that describes the operational outline of the system. The context diagram describes the relationship of the system with entities outside the system. CD shows the system a process. [4]

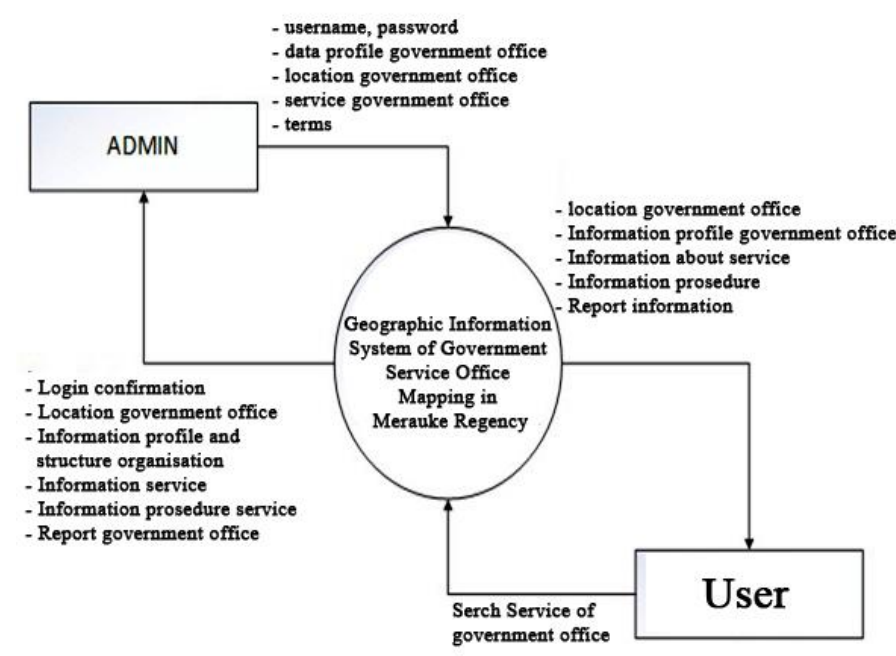

Fig. 2. Diagram Context

\section{Data Flow Diagram (DFD)}

It is an elaboration of the previously designed context. DFD which in Indonesian is referred to as DAD (Data Flow Diagram) shows an overview of input processes from a system/software, ie data objects flow into the software, then transformed by processing elements, and objects the result data will flow out of the system/software. [5]

1) Process 1.0 is login process: Admin inputs the data of user and password to get administrator access on the system.

2) Process 2.0 is user management process: Admin can add new data or remove the existing user data on the system. The output will display the user data registered as admin.

3) Process 3.0 is process of recording office type. Admin inputs data of the office type into the system: The output displays data of office type entered in the system.

4) Process 4.0 is process of recording office profile: Admin inputs office data such as identity, name, and profile into the system. The output displays data in the form of profile of each service office entered to the system.

5) Process 5.0 is process of recording service data: Admin inputs the service type of all government service office into the system. The output displays all service data as well as the service's procedure inputted to the system.

6) Process 6.0 is process of recording office detail and service: Admin input detail data by connecting data to the office table and service table into the system. The output of the office detail will display complete data of the office and service that are available on the government service office.

7) Process 7.0 is process of displaying result: Admin receives information of data that has been inputted. Fig. 3 show Data Flow Diagram. 


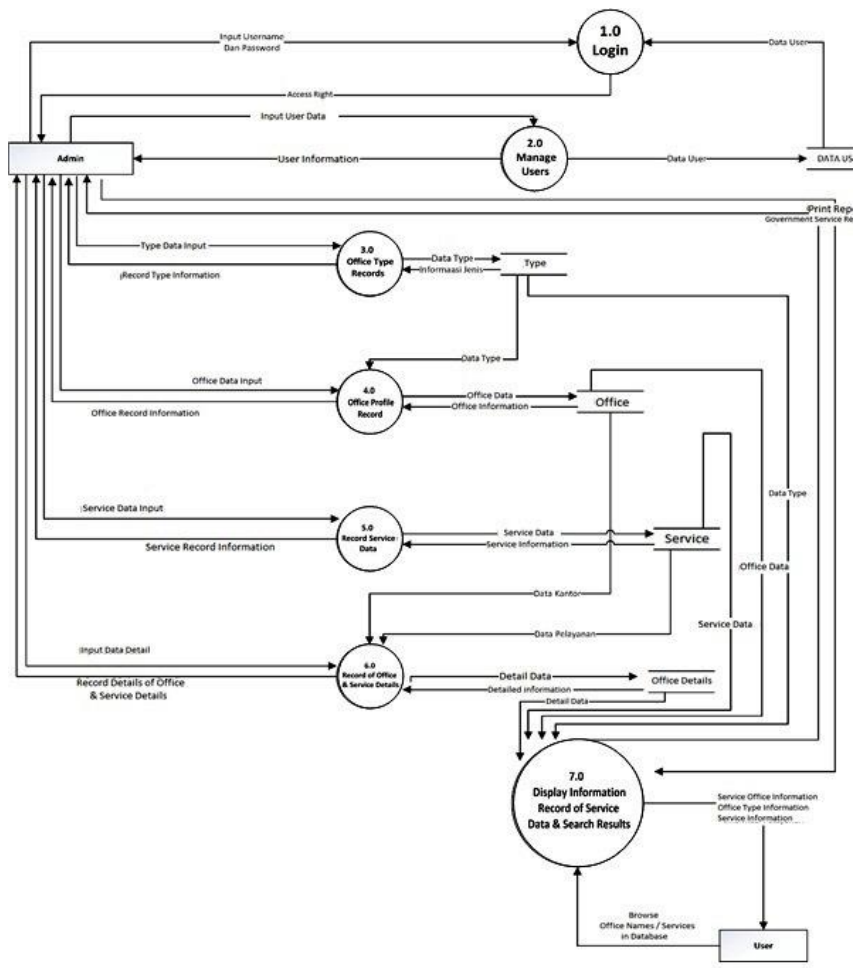

Fig. 3. Data Flow Diagram (DFD)

\section{RESULT AND DISCUSSION}

The implementation stage is part of the results per analysis that exist in the right context. Implementation of the interface of the software is done based on the design that has been made. Software Testing is the process of implementing a program or system with the aim of finding various activities that aim to identify attributes or programs or systems and determine that it is the results needed by the company [6].

\section{A. Home Page}

Fig. 4 shows the home page of Application of Geographic Information System of Service Office Mapping in Merauke.

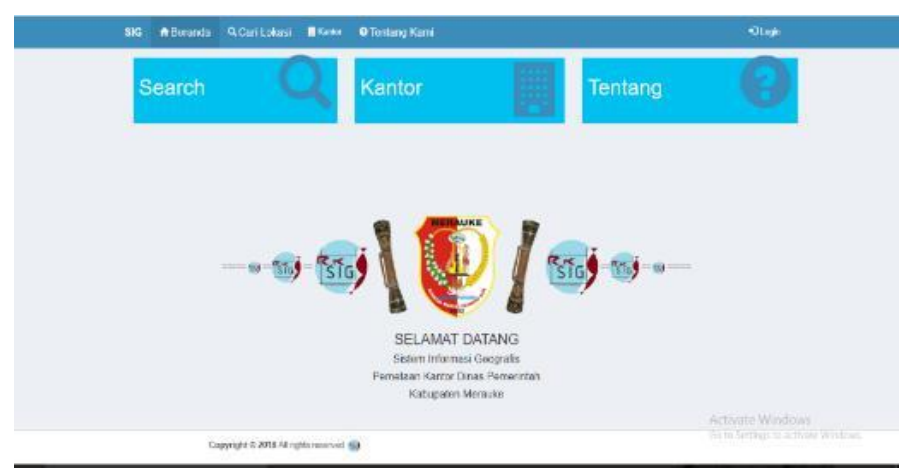

Fig. 4. Home Page

\section{B. Office Search Page}

Office Search page can describe that to search for office as in Fig. 5, the user must input keyword of office's name or type of service, and then click search button. If the user wants to classify the search based on the district, choose the desired district, and then the system will automatically display agencies in the district.

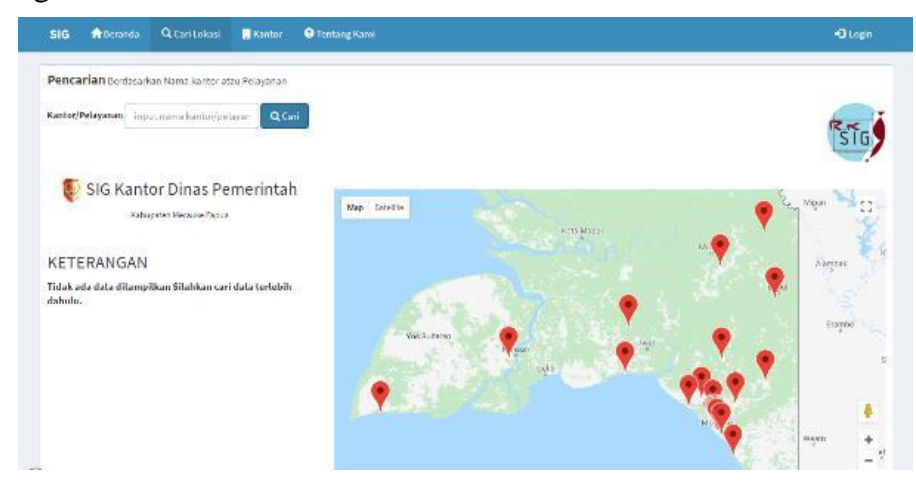

Fig. 5. Office Search Page

\section{User Form Page}

Fig. 6 shows user form page; the function of user form is to input user data that will be saved in the system.

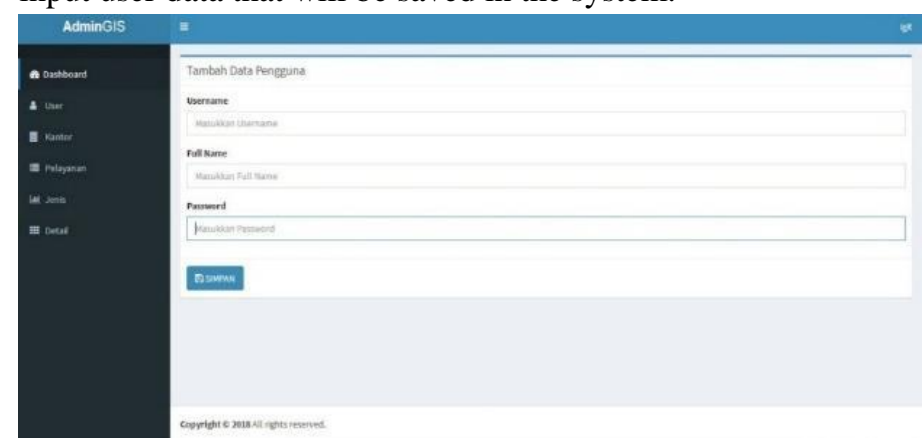

Fig. 6. User Form Page

\section{Office Form Page}

Fig. 7 shows office form, which purpose is to add data of office into the system.

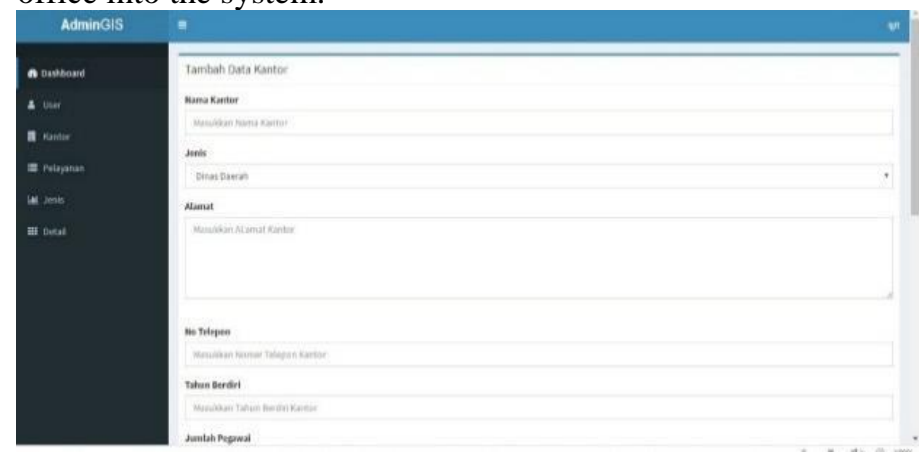

Fig. 7. Office Form 


\section{E. Type Form Page}

Type input form is to add data of office type into the system.

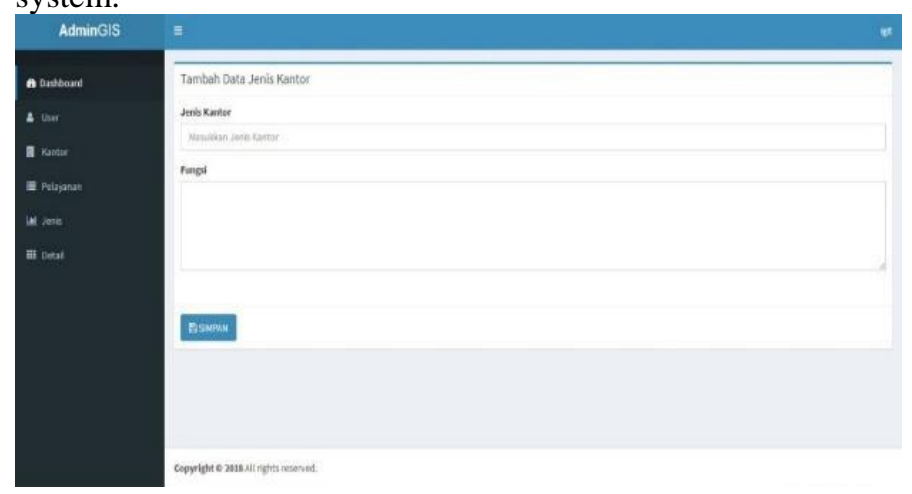

Fig. 8. Type Form

\section{F. Service Form Page}

Service form describes that all service data inputted will be displayed on the service menu. Menu for adding new service data is by clicking create.

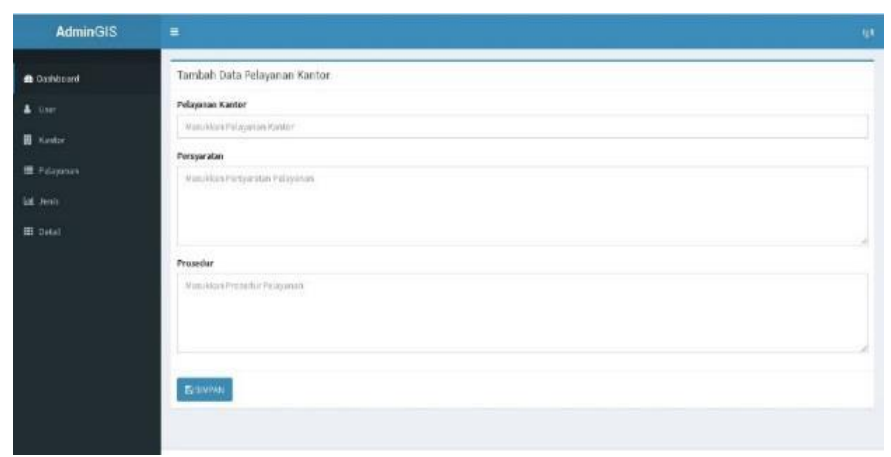

Fig. 9. Service Form

\section{G. Office Detail Page}

Office detail page shows that all data about office detail that has been inputted will be displayed on the detail menu.

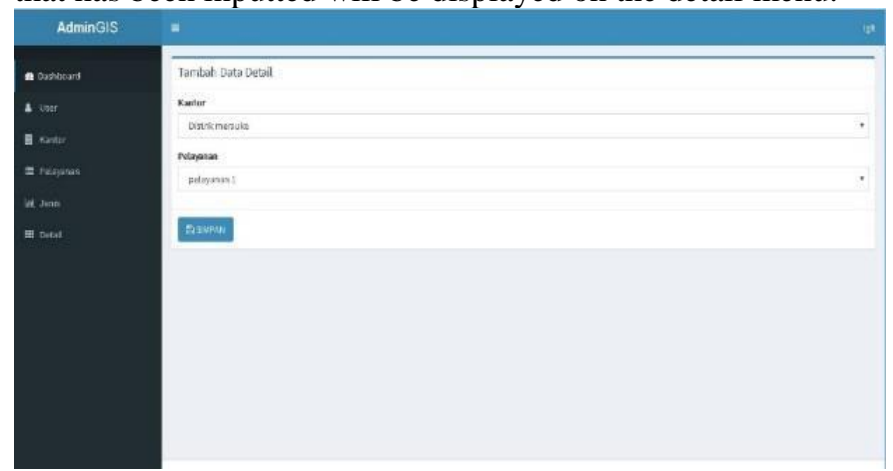

Fig. 10. Office Detail Page

\section{H. Admin's Questionnaire Result}

This is the result of system testing using questionnaire method on the admin.

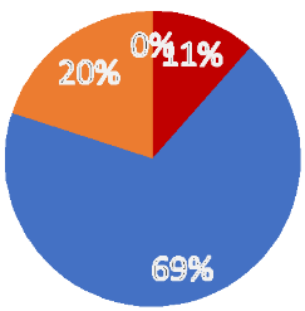

Very good $\square$ Good $\square$ Poor $\square$ Very Poor

Fig. 11. Admin's Questionnaire Diagram

\section{User's Questionnaire Result}

This is the result of system testing using questionnaire method on the user.

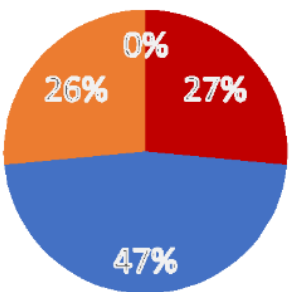

Very good $\square$ Good $\square$ Poor $\square$ Very Poor

Fig. 12. User's Questionnaire Diagram

\section{CONCLUSION}

System testing using black box and questionnaire methods is to obtain respondents' opinion about function and quality of the program that has been made. The system can display the information of office service as well as procedures at the government service office in Merauke Regency.

\section{ACKNOWLEDGMENT}

We thank Universitas Musamus for facilities, supports, and publications.

\section{REFERENCE}

[1] BPS Merauke Regency, "Merauke Regency in Figures," 2017 ed., Merauke: BPS Kabupaten Merauke/BPS-Statistics of Merauke Regency, pp. $1-425,2017$.

[2] K.M. Wibowo, I. Kanedi, and J. Jumadi, "The Geographic Information System (GIS) determines the location of coal mining in the Bengkulu Province website," J. Media Infotama Vol., vol. 11, no. 1, pp. 51-60, 2015.

[3] Hamidi, "Web-based geographic information system application deployment of school operational funds," J. Masy. Inform., vol. 2, no. 3, pp. 1-14, 2011.

[4] E. Iswandy, "Decision support system to determine the receipt of nagari child social compensation funds and their distribution for underprivileged students and students in East Kenagarian Barung Barung Balantai," Teknoif, vol. 3, no. 2, pp. 70-79, 2015.

[5] R. Afyenni, "Designing data flow diagrams for school information systems (case studies at high school UNP laboratory development)," Teknoif, vol. 2, no. 1, pp. 35-39, 2014.

[6] M. Komarudin, "Software testing black-box method based on equivalence partitions on the application of school information systems," Mikrotik, vol. 6, no. 1, 2016. 